\title{
Technical Analysis of Kort Nozzle Application for SPOB Ship 4990 DWT on River
}

\author{
Tony Bambang Musriyadi ${ }^{1}$, Amiadji ${ }^{2}$ and Bayu Sukma Cahyono ${ }^{3}$.
}

\begin{abstract}
- propeller is a locomotor shaped vanes are used to drive ships, and also propellers which serves to move tehaga by changing the turning force of the propeller thrust menggerakakan into the vessel. In increasing the value of the thrust to be generated that is by applying the kort nozzle propeller. The method used in this study using CFD (Computional Fluid Dynamic), and the variation is from the conventional propeller models, with a kort nozzle propeller type kort nozzle type 19A and 37. Based on the findings that the kort nozzle propeller with the addition of the value of the thrust , propeller efficiency and torque generated. The driving force value is by using kort nozzle propeller type 37 amounted to $349.27 \mathrm{kN}$.
\end{abstract}

Keywords-kort nozzle, SPOB, thrust

\section{INTRODUCTION}

\section{$\mathrm{S}$} tanker which has its own propulsion system. Differences SPOB ship with Oil Barge is located on the propulsion system, if the ship SPOB has its own propulsion system, while the Oil Barge vessel has no propulsion system of its own, but drawn using Tug Boat.

Most ships SPOB using propeller propulsion system, but the system has a weakness in the fluid flow to the propeller. Where the hull shape SPOB shaped pontoon Flat Bottom with a recess in the stern resulting fluid flow only dominated from the Bottom. So that the propeller rotation efficiency decreases and affects the resulting thrust force [1][4].

SPOB ship today not only operates on the high seas, but also in some rivers in Indonesia, due to the Offshore activity is now focused not only on the high seas. However, there is a government regulation number 52 of 2012 which states that vessels operating on rivers in Indonesia maximum boat speed of $10 \mathrm{~km} / \mathrm{h}$ or can be of 5.39 knots. This is exactly what makes the Owner to innovate not use large-capacity Main Engine but get maximum thrust, so that the desired speed is reached [5].
Many technologies boats that have been created to solve the problem, for example the use of Water Jet propulsion system and Azipod system [10]. But the technology less attractive because the cost of purchasing and maintenance (Maintenance) is relatively high. So the ship innovating technology experts to implement ducted technology called "Kort nozzle" [3].

Kort Nozzle itself been many shipowners due to the terms of the purchase costs and lower maintenance dibandingakan with other propulsion technologies. Kort Nozzle propeller itself is a wrapper in the form of plateshaped foil. The working principle of the Kort nozzle is a concentrated stream of water flowing into the propeller so as to maximize the water to be absorbed by the propeller. It aims to maximize the work so that the propeller thrust generated is also maximized.

\section{LITERATURE REVIEW}

Kort Nozzle or Nozzle is in the form of protective propeller-shaped plate Foil. Function of Nozzle is improving and centralizing the flow of water flowing into the propeller so as to maximize the water is sucked propeller. It aims to maximize the work so that the propeller thrust generated is also maximized. The
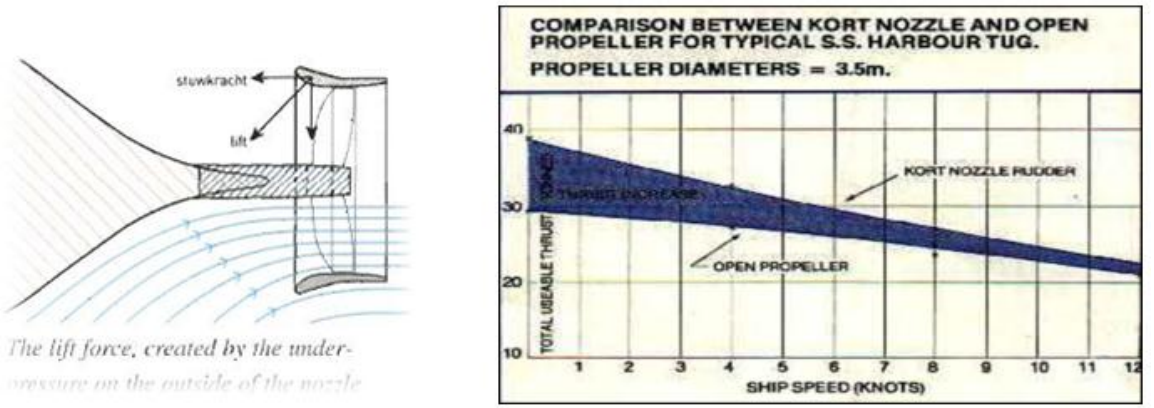

Figure 1. Income water flow diagram and Comparison chart performance compared Kort Nozzle Open Propeller (Henderson, 1963)

Tony Bambang Musriyadi, Department of Marine Engineering, Institut Teknologi Sepuluh Nopember, Surabaya 60111, Indonesia, Email : tobal@its.ac.id

Amiadji, Department of Marine Engineering, Institut Teknologi Sepuluh Nopember, Surabaya 60111, Indonesia, Email: amiadji@yahoo.com

Bayu Sukma Cahyono, Department of Marine Engineering, Institut Teknologi Sepuluh Nopember, Surabaya 60111, Indonesia, Email: bayusukmacahyono.14@gmail.com efficiency of the force generated will be maximized if the water dpat Nozzle pass freely without hindrance. In principle, the nozzle can be used any kind of fast boats.[2]

Kort Nozzle often used for inland vessels, Suction Hopper, Dredger, Tug Boat, Fishing Ship and boat SPOB. Advantages and disadvantages of Fixed or 
Controllacle Pitch Propeller is the same as the Kort nozzle propeller wear or not to wear it. In terms impetus same figure can be given with a small diameter Kort nozzle [6].

\section{A. Force Drag and Force Lift}

Voltage multiplied by each area in which they will work to produce force. While the number of these forces on a piece must remain in balance. Another component of the intensity of the forces acting parallel to the plane of the elementary area [8]. Components of the intensity of this force called shear teganga. This is denoted by $\tau$. Mathematically defined as follows:

$\tau=\lim _{A \rightarrow 0} \frac{\Delta V}{\Delta A}$

So as to obtain a mathematical formula frictional forces, equation 1 can be written as follows:

$\mathrm{F}=\tau \times \mathrm{A}$

Meanwhile, to get lift mathematical formula, equation 1 can be written as follows:

$\mathrm{F}=\mathrm{P} \times \mathrm{A}$

\section{B. Thrust}

The driving force of the ship is an important component, which is used to overcome the resistance or drag vessels. In ideal conditions, the amount of thrust required may be the same as the drag is happening on the ship[8]. Thurst mathematical formula can be drawn from the blade element momentum theory. Thrust force equation can be written as follows:

$F=F_{\text {lift }} \cos \theta-F_{\text {drag }} \sin \theta$

\section{Blade Element Momentum Theory}

Blade element momentum theory is a theory that combines blade element theory and the theory of momentum, is used to calculate the forces acting on the vane or turbine [11]. Blade element theory combined with the theory of momentum to alleviate some of the difficulties in calculating the speed of the rotor caused, see figure 1 [9].

The equation used for the forces acting on the blade are as follows:

$$
\begin{aligned}
& F_{\Theta}=F L \cos \theta-F D \sin \theta \\
& F_{z}=F L \sin \theta+F D \cos \theta
\end{aligned}
$$

\section{Torque}

Ability twist given to an object, causing the object rotates is called torque. Torque or moment of force is the product of the force and the moment arm[8]. Can also be written by the equation:

$\tau=r x F$

So that the torque acting on a blade based on the equations 6 and 7 are as follows:

$Q=\left(F_{\text {lift }} \sin \Theta+F_{\text {drag }} \cos \theta\right) \times r$

\section{E. Propeller Efficiency}

Propeller Efficiency is the ratio of thrust to the force supplied, a power conversion efficiency and value differences that occur are located in which the propeller torque measurement is done. The measurements were carried out on the open water [7]. The equation below shows the efficiency of the propeller, as follows:

$\eta_{Q}=\frac{P_{T}}{P_{D}}=\frac{\tau V}{2 \pi Q+1}=\frac{K_{T} \rho \mathrm{t}^{2} D^{4} V}{2 \pi K_{Q} \mathrm{n}^{2} D^{5}}=\frac{K_{T}}{2 \pi} \frac{V}{\pi D D} \frac{1}{K_{Q}}=\frac{K_{T}}{K_{Q}} \frac{I}{2 \pi}$

\section{RESULTS AND DISCUSSION}

At this stage of data analysis in the form of process modeling and simulation at the kort nozzle propeller and its discussion. First, there will be described the process of making a model of the data obtained. Then in the next sub-chapter will do the simulation process using Ansys software (CFD). The results of the simulation process will be used as a parameter to select the type kort nozzle fatherly effective for SPOB 4990 DWT ships.

\section{A. Key Data Ships}

The main data needed to draw the model and simulated in these experiments is:

Data Propeller

Propeller type : NOZP

Rotation : Right

Number of Blades $\quad: 4$

Diameter : $2000 \mathrm{~mm}$

Material type : : Bronze

Rpm : 293

Skew : :4.6 Deg

Rake Of GL Aft $\quad: 7$ Deg 
International Journal of Marine Engineering Innovation and Research, Vol. 1(3), Jun. 2017. 168-174 (pISSN: 2541-5972, eISSN: 2548-1479)

$\begin{array}{ll}\text { Loa } & : 90.4 \mathrm{~m} \\ \text { Breatdh } & : 24.0 \mathrm{~m} \\ \text { Depth } & : 5.5 \mathrm{~m} \\ \text { Draft } & : 3.9 \mathrm{~m} \\ \text { Vs } & : 6 \text { knots } \\ \text { DWT } & : 4990 \text { ton }\end{array}$

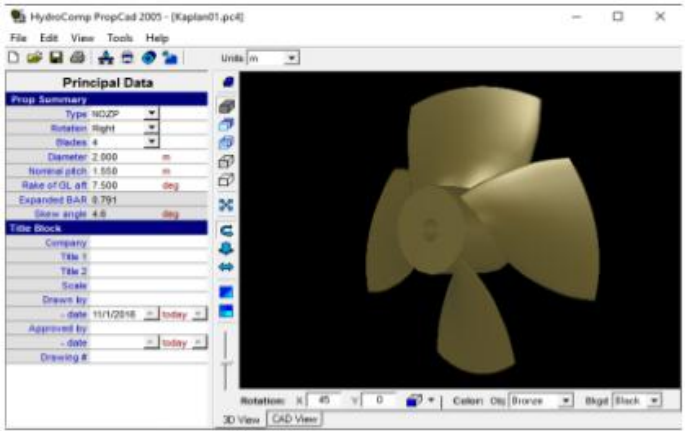

(a)
B. Simulation Process using Ansys Software (CFD)

At this stage we discuss data simulation ship using CFD software, there are some steps done that redesign propeller (a), redesign kort nozzle (b), geometry (c), boundry (d), meshing (e), solver manager (f), and post processing (g). Figure 2-4 displays ship data simulation from a-g and Table 1 shows the value of area, pressure, and wall shear ship data simulation results from CFD software.

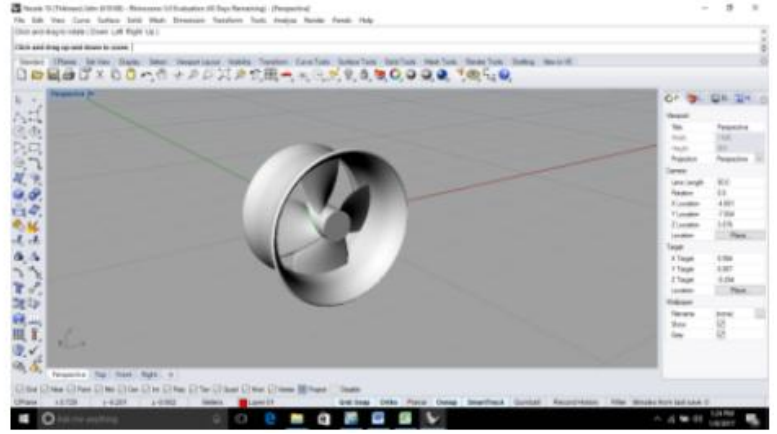

(b)

Figure 2. redesign propeller(a), redesign kort nozzle(b)

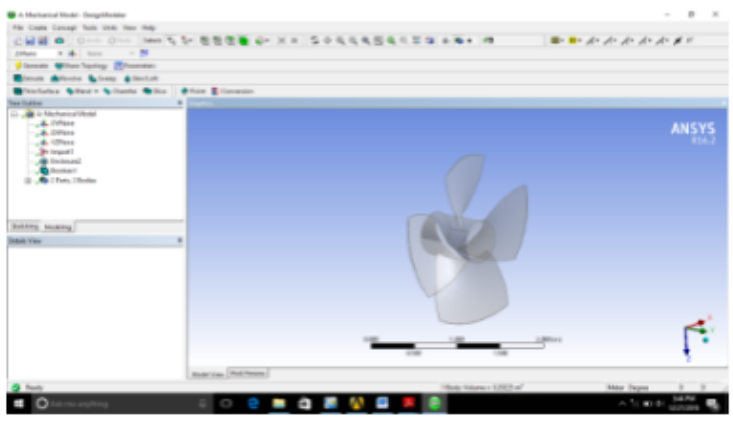

(c)

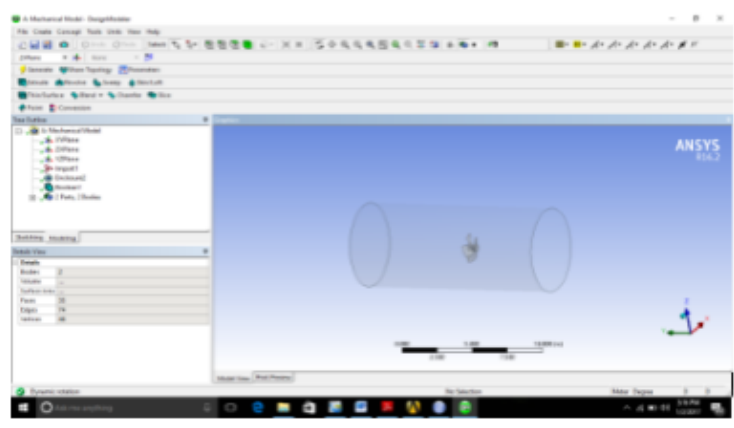

(d)

Figure 3. geometry (c), boundry (d)

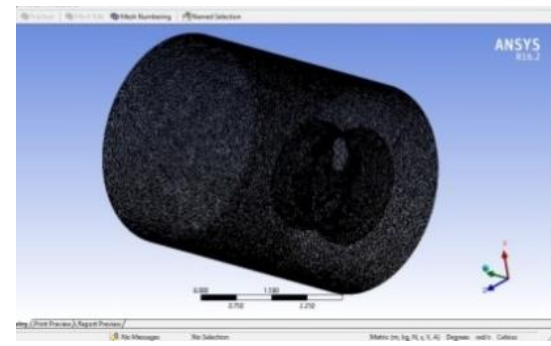

(e)

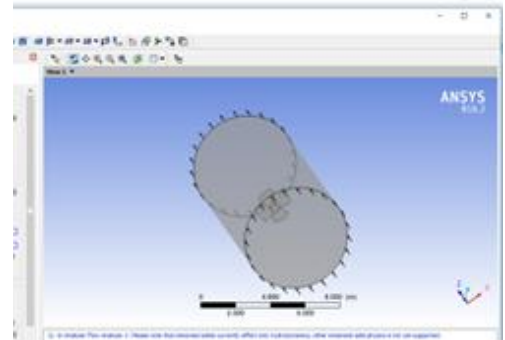

(f) )

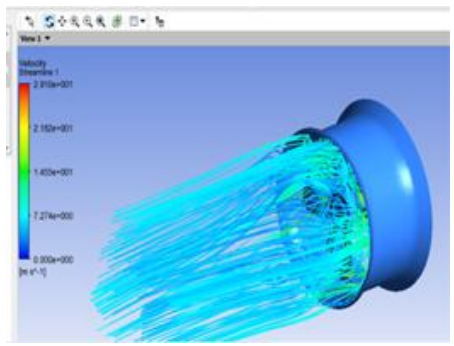

$(\mathrm{g})$

Figure 4. meshing (e), solver manager (f), and post processing (g) 
TABLE 1.

DATA SIMULATION RESULTS PROPELLER

\begin{tabular}{|c|c|c|c|c|c|}
\hline $\begin{array}{l}\text { Types of } \\
\text { propeller }\end{array}$ & $\begin{array}{c}\text { Size } \\
\text { meshing } \\
(\mathrm{mm})\end{array}$ & & $\begin{array}{l}\text { Area } \\
\left(\mathrm{m}^{2}\right)\end{array}$ & $\begin{array}{l}\text { Pressure } \\
\text { (pa) }\end{array}$ & $\begin{array}{l}\text { Wall shear } \\
\text { (pa) }\end{array}$ \\
\hline \multirow{6}{*}{ 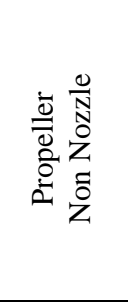 } & \multirow{2}{*}{70} & Face & 6,628 & 36321 & 1828 \\
\hline & & Back & 6,747 & 28479 & 1945 \\
\hline & \multirow{2}{*}{50} & Face & 6,615 & 35864 & 1570 \\
\hline & & Back & 6,746 & 19950 & 1719 \\
\hline & \multirow{2}{*}{30} & Face & 6,602 & 34951 & 1208 \\
\hline & & Back & 6,668 & 12950 & 1419 \\
\hline \multirow{6}{*}{ 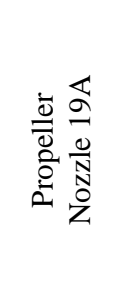 } & \multirow{2}{*}{70} & Face & 6,628 & 39183 & 2362 \\
\hline & & Back & 6,747 & 31663 & 2688 \\
\hline & \multirow{2}{*}{50} & Face & 6,615 & 39048 & 2104 \\
\hline & & Back & 6,746 & 23134 & 2253 \\
\hline & \multirow{2}{*}{30} & Face & 6,602 & 38135 & 1543 \\
\hline & & Back & 6,668 & 17134 & 1742 \\
\hline \multirow{6}{*}{ 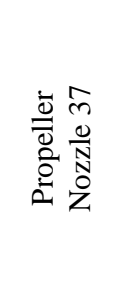 } & \multirow{2}{*}{70} & Face & 6,628 & 45763 & 2707 \\
\hline & & Back & 6,747 & 26503 & 2474 \\
\hline & \multirow{2}{*}{50} & Face & 6,615 & 41413 & 2216 \\
\hline & & Back & 6,746 & 20935 & 2173 \\
\hline & \multirow{2}{*}{30} & Face & 6,602 & 38714 & 1797 \\
\hline & & Back & 6,668 & 16752 & 1964 \\
\hline
\end{tabular}

\section{Data Calculation}

At this stage will display the results of calculation of the value of data in the form of a lift force and drag force on the face and back area, calculating the value of thrust, torque, and efficiency propeller. And followed by calculation of the percentage difference between the value of thrust each meshing size for each model kort nozzle. Data calculation results are presented in Table 2, and for percentage difference between the value of thrust presented in Table 3.

TABLE 2 .

Data Calculation Results of Lift, DRAG, THRUts, TORQUe AND EFFICIENCY PROPELlER

\begin{tabular}{|c|c|c|c|c|c|c|}
\hline $\begin{array}{l}\text { Types of } \\
\text { Propeller }\end{array}$ & $\begin{array}{c}\text { Size } \\
\text { Meshing } \\
(\mathrm{mm})\end{array}$ & $\begin{array}{l}\text { Total } \\
\text { Lift }\end{array}$ & $\begin{array}{l}\text { Total } \\
\text { Drag }\end{array}$ & $\begin{array}{c}\text { Thrust } \\
(\mathrm{kN})\end{array}$ & $\begin{array}{l}\text { Torque } \\
(\mathrm{kNm})\end{array}$ & $\begin{array}{l}\text { Efficiency } \\
\text { Propeller }\end{array}$ \\
\hline \multirow{3}{*}{ 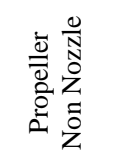 } & 70 & 432883,401 & 25238,899 & 412,69 & 84,23 & 0.497 \\
\hline & 50 & 371823,064 & 21981,924 & 354,40 & 72,06 & 0,495 \\
\hline & 30 & 317097,101 & 17437,108 & 302,57 & 62,72 & 0,485 \\
\hline \multirow{3}{*}{ 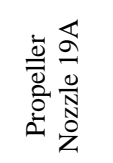 } & 70 & 473335,185 & 33791,272 & 449,70 & 86,13 & 0,525 \\
\hline & 50 & 414364,484 & 29116,698 & 393,79 & 75,83 & 0,522 \\
\hline & 30 & 366016,782 & 24523,288 & 348,14 & 68,14 & 0,514 \\
\hline \multirow{3}{*}{ 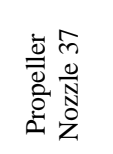 } & 70 & 482132,905 & 35308,774 & 457,83 & 86,85 & 0,530 \\
\hline & 50 & 412174,505 & 29317,898 & 394,52 & 75,84 & 0,523 \\
\hline & 30 & 367292,164 & 24959,746 & 349,27 & 68,03 & 0,516 \\
\hline
\end{tabular}

\section{Data Calculation Graph}

The data analyzed in the previous section will then be put in the form of graphs, so that later it can be concluded the characteristics of each model has been simulated.
Chart to be displayed is a graph of the lift and drag on any model is presented in Figure 5, a graph comparison of the value of thrust and size meshing in Figure 6, as well as a comparison chart an efficiency propeller and thrust values in Figure 7. And comparison chart Thrust value and torque in Figure 8. 
International Journal of Marine Engineering Innovation and Research, Vol. 1(3), Jun. 2017. 168-174 (pISSN: 2541-5972, eISSN: 2548-1479)

TABLE 3

Calculation Result Percentage Difference Value Thrust

\begin{tabular}{|c|c|c|c|c|}
\hline Types of Propeller & $\begin{array}{l}\text { Size Meshing } \\
\quad(\mathrm{mm})\end{array}$ & $\begin{array}{l}\text { Thrust Propeller Non } \\
\text { Nozzle (kN) }\end{array}$ & $\begin{array}{l}\text { Thrust Propeller Nozzle } 37 \\
(\mathrm{kN})\end{array}$ & Persentase $(\%)$ \\
\hline \multirow{3}{*}{ 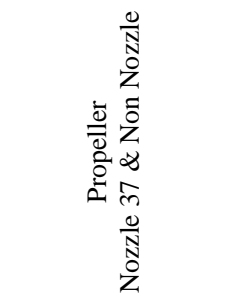 } & 70 & 412,69 & 457,83 & 10,69 \\
\hline & 50 & 354,40 & 394,52 & 12,22 \\
\hline & 30 & 302,57 & 349,27 & 15,96 \\
\hline \multirow{3}{*}{ 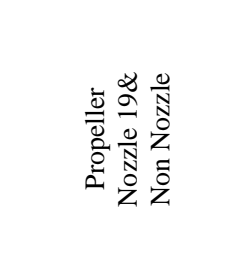 } & 70 & 412,69 & 449,70 & 9,09 \\
\hline & 50 & 354,40 & 393,70 & 11,09 \\
\hline & 30 & 302,57 & 348,14 & 12,90 \\
\hline \multirow{3}{*}{ 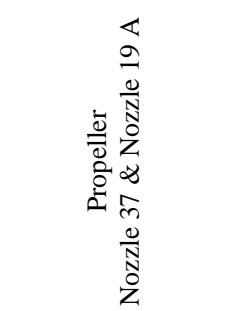 } & 70 & 457,83 & 449,70 & 1,46 \\
\hline & 50 & 394,52 & 393,70 & 1,01 \\
\hline & 30 & 349,27 & 348,14 & 2,70 \\
\hline
\end{tabular}

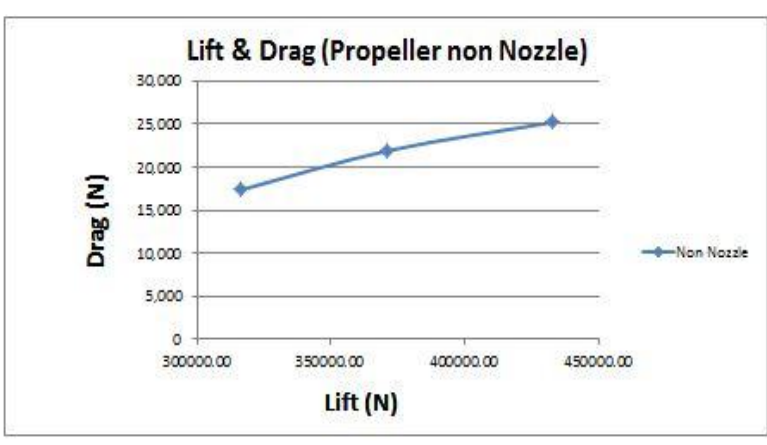

(a)

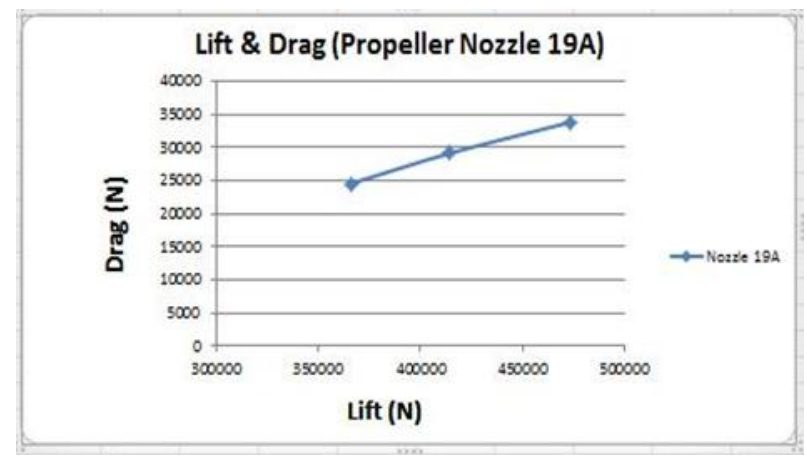

(b)

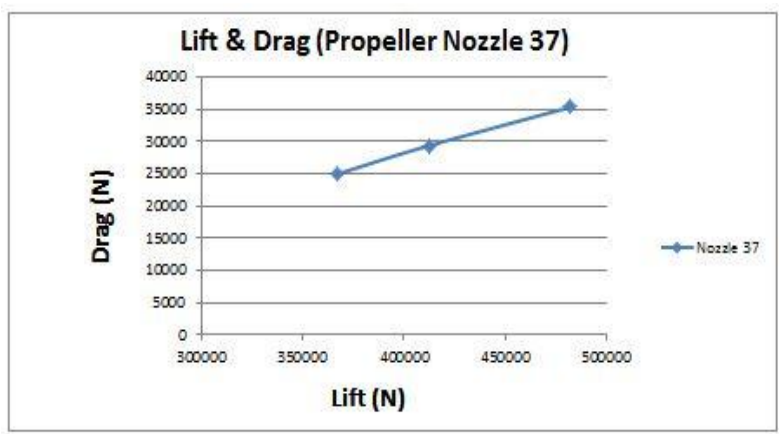

(c)

Figure 5. Graph Lift \& Drag Propeller 


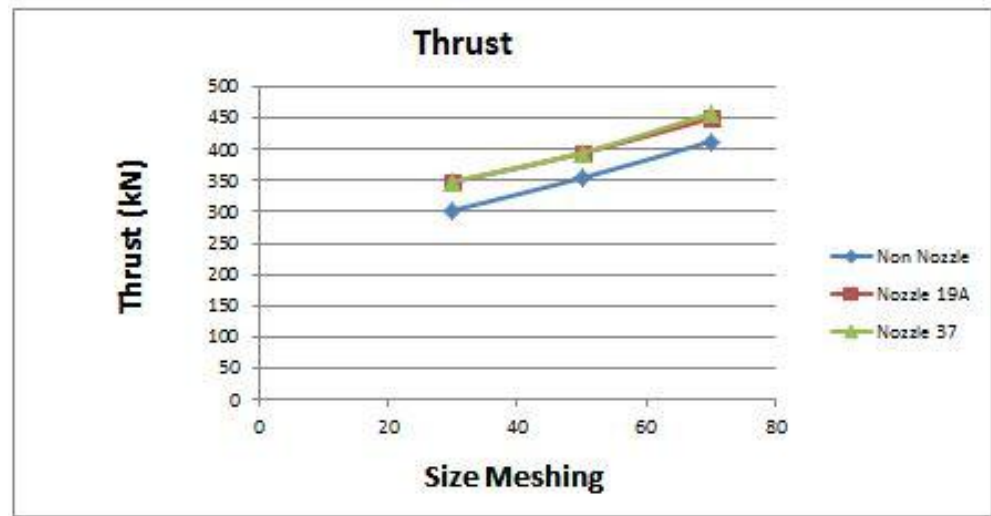

Figure 6. Graph Comparison of the Thrust Value and Size Meshing

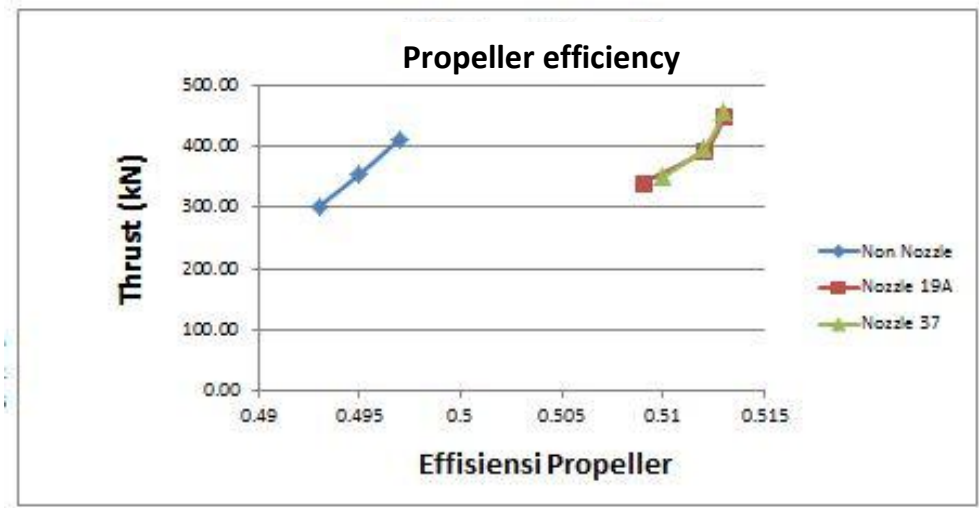

Figure 7. Graph Comparison of the Thrust Value and Propeller Efficiency

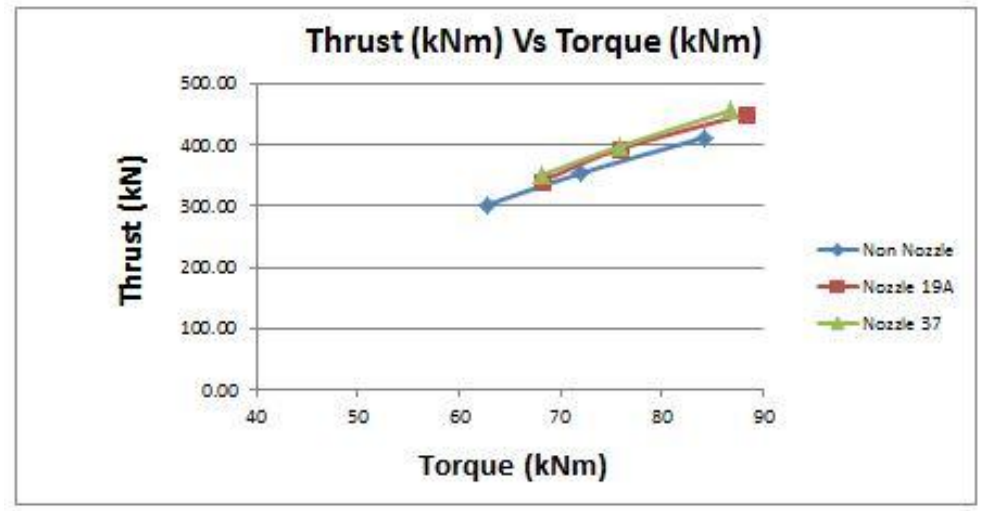

Figure 8. Graph Comparison of the Thrust Value and Torque

E. Validation Simulation

Based on research that has been done is the comparison kort nozzle 19 A to 37 in terms of fabrication and functional, as follows:

- Kort Nozzle 19

In the fabrication process is seen from the surface of the straight line in the middle and identical straight on the back, making it easier to bend fabrication because only in the front chamber (Leading Edge).

\section{- Kort Nozlle 37}

Cross-sectional shape that straight line only in the middle and large camber on the front and rear will make fabrication easier. Because bending great on the front camber (Leading Edge) and rear camber (Trailing Edge). Based on the functional states that the type kort nozzle 37 better to nudge forward and backward, because that construction of a kort nozzle 37 is large chamber at the front and rear. Kort nozzle with type 37 is also better for the performance of a big push for low propeller rotation. 


\section{CONCLUSION}

From the simulation results and analysis in the previous chapter stated that the smaller meshing the value of thrust and efficiency of propeller produced has a high degree of accuracy, and it can be concluded that the value of thrust and efficiency of the propeller that does not use a nozzle that has a thrust of $302 \mathrm{kN}$ and efficiency propeller 0.485 , with the propeller thrust nozzle 19A has a value of 348.14 with a propeller efficiency value of 0,514 and propeller with a nozzle 37 have the value of efficiency propeller thrust 349.27 with 0.516 .

The results of the simulation and analysis already done that type of nozzle propeller with 37 more recommended on SPOB 4990 DWT vessels in waters of the river because it has a propeller thrust and better efficiency.

\section{REFERENCES}

[1] SPOB (Self Propeller Oil Barge),2016. /SPOB - Wikipedia, the free encyclopedia.htm. Tanggal 29 Juli 2016. Pukul 09.00

[2] Oil Barge and Marine Kort Nozzle,2016. http://www.splashmaritime.com.au/Marops/data/less/Mano/Kort\% 20nozzels.htm. Tanggal 31 Juli 2016. Pukul 13.00

[3] Ship Knowledgement Modern Encyplodia., (2010). Propulsion and Steering Gear, Chapter 12

[4] Widyanto,"Analisa Aliran pada Ducted Propeller dengan Pendekatan CFD (Computational Fluid Dynamics)", Jurusan Teknik Sistem Perkapalan, Fakultas Teknologi Kelautan, Institut Teknologi Sepeluh Nopember Surabaya, 2012.

[5] Peraturan Menteri Perhubungan Republik Indonesia Nomor PM. 52,"Alur-Pelayaran Sungai dan Danau", 2012.

[6] Sv. Aa Harvald, 1992, Tahanan dan Propulsi Kapal, Airlangga University, Press Surabaya.

[7] 1999, ITTC, "Propulsion, Propulser Open Water Test," dalam International Towing Tank Conference, Seoul/Shanghai, 2002.

[8] E. Popov, Mekanika Teknik, Jakarta: Erlangga, 1989

[9] E. Kulunk, Aerodynamics of Wind Turbines, fundamental and Advance Topics in Wind Power, InTech, 2011.

[10] A. Santoso, J. Prananda, A. Amiadji, E. Jadmiko, and I. A. Murtadha, "Flat Top Barge 300 feet Using Portable Dynamic Positioning System,” Int. J. Mar. Eng. Innov. Res., vol. 1, no. 2, Mar. 2017.

[11]M. Mukhtasor, T. B. Musriyadi, I. S. Arief, and A. W. C. Saputra, "Horizontal Pendulum Performance Analysis with Multilevel Model Plate on Ocean Wave Electric Power Plant (PLTGL)," Int. J. Mar. Eng. Innov. Res., vol. 1, no. 2, Mar. 2017. 